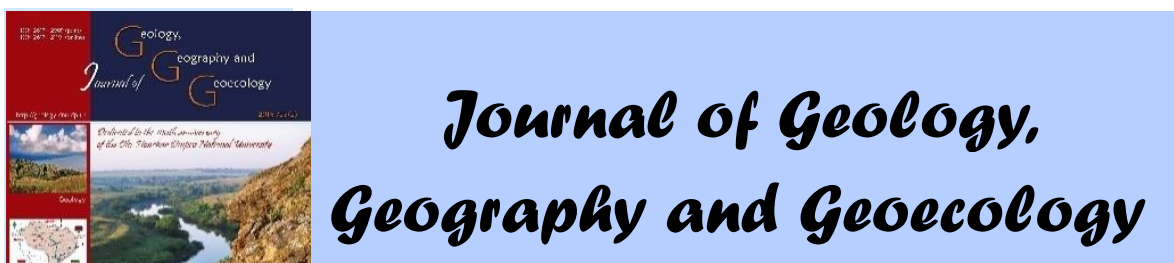

Journal home page: geology-dnu-dp.ua

G.K. Kovalchuk, V.K. Lebedieva,

L.M. Savchuk, L.M. Bandorina

Journ.Geol.Geograph.Geoecology, 28(1), 87-94

\title{
Economic geographical aspects of development of the regions of Ukraine
}

\author{
G.K. Kovalchuk, V.K. Lebedieva, L.M. Savchuk, L.M. Bandorina \\ National Metallurgical Academy of Ukraine, Dnipro, Ukraine, e-mail: lebtoval@gmail.com
}

Received 28.12.2018;

Received in revised form 14.01.2019;

Accepted 10.03.2019

The objective of the article was to determine the orientations of the development of the economic regions of Ukraine in relation to their complex provision with resources and economic-geographic position. Management of territorial development as a sphere of economic-geographic activity includes formation of regional statistics, social-economic zoning, geoexpertise and geoinformatics. They allow assessment of the economic regions as regional economic systems taking into account the impact of local peculiarities on economic activity. Territorial systems of different types have both common and specific peculiarities. Correlation and interaction of these systems increase as the productive forces develop and are manifested to a higher extent within economic regions. An economic region is a fundamental regional structure which has a certain economic self-sufficiency and property of self-organization. Economic-geographic prediction is one of three types of geographic forecasting along with physical-geographic and geoeconomic. Economic-geographic forecasting determines the possible condition of a territorial social-economic system in the future. To ensure greater reliability of economicgeographic forecasts, it is suggested that one takes into account not only the economic-geographic, but also the geopolitical position of a region. To the traditional components of economic-geographic position of region, such components are also added as financialgeographic position and innovation-geographic position. The abovementioned theoretical economic-geographic bases allowed assessment of the condition and potential for the development of the economic regions of Ukraine, and also prediction of possible scenarios of their development. The results of the study enabled us to suggest particular measures of an economic-geographic character in relation to Carpathian, Volyn, North-East, Podillia, Prydniprovsky, Prychornomorsky, East and Central-Ukrainian economic regions.

Keywords: regional economic geography, economic region, management of territorial development, economic-geographical forecasting, financial-geographic position, innovation-geographic position.

\section{Економіко-географічні аспекти розвитку регіонів України}

\author{
Г.К. Ковальчук, В.К. Лебедєва, Л.М. Савчук, Л.М. Бандоріна
}

Національна металургійна академія Украӥни, Дніпро, Украӥна, е-таil: lebtoval@gmail.com

Анотація. Метою статті $є$ визначення напрямів розвитку економічних районів України відповідно їх комплексному ресурсному забезпеченню та економіко-географічному положенню. Управління територіальним розвитком як сфера економіко-географічної діяльності включає в себе формування регіональної статистики, соціально-економічне районування, геоекспертизу та геоінформатику. Вони дозволяють здійснити оцінювання економічних районів як регіональних господарчих систем $з$ урахуванням впливу місцевих особливостей на господарчу діяльність. Територіальні системи різних видів мають як спільні, так і специфічні властивості. Узгодженість та взаємозв'язок цих систем посилюються з розвитком продуктивних сил і в найбільшій мірі проявляються в межах економічних районів. Саме економічний район $\epsilon$ фундаментальною регіональною структурою, що має певну господарчу самодостатність та властивість самоорганізації. Економіко-географічне прогнозування є одним 3 трьох видів географічного прогнозування разом з фізико-географічним та геоекономічним. Економіко-географічний прогноз визначає можливий стан територіальної соціально-економічної системи у перспективі. У якості методологічної основи економіко-географічного прогнозування використовується системний підхід. Для забезпечення достовірності економіко-географічних прогнозів пропонується враховувати не тільки економікогеографічне, але й геополітичне положення регіону. До традиційних складових економіко-географічного положення регіону додаються такі, як фінансово-географічне положення та інноваційно-географічне положення. Зазначені теоретичні економіко-географічні засади дозволили дати оцінку стану та потенціалу розвитку економічних районів України, а також спрогнозувати можливі сценарії їх розвитку. Результати дослідження дозволили запропонувати конкретні заходи економікогеографічного характеру у відношенні Карпатського, Волинського, Північно-Східного, Подільського, Придніпровського, Причорноморського, Східного та Центральноукраїнського економічних районів. 
Ключові слова: регіональна економічна географія, економічний район, управління територіальним розвитком, економікогеографічне прогнозування, фінансово-географічне положення, інноваційно-географічне положення.

Introduction. Economic regions, as objects of study of regional economic geography, are important components of the territorial organization of the economic life of society. The spatial peculiarities of economies are some of the essential factors of their development. The strategy of development of Ukraine requires certain changes in the location of social production within the economic regions as territorial-economic systems. This problematic has been described in the studies by such scientists as V. Udovichenko, N. Clefford, S. French, G. Valentino, B. Gomez, J. Jones, M. Palamarchuk, L. Pasenko, B. Neshtaiev, S. Siutkin, M. Hvesik, K. Kolomiets, M. Baranovsky. Realization of these requirements should be based on the principles of new economic geography, which take into account the possibility of increasing productivity from use of resources. Increase in the productivity of resources is an important argument at making decisions on changes in spatial economic structure. One of the conditions of such changes is flow of workforce in quantitative and qualitative aspects in relation to complex provision of the economic regions with resources. The determination of the orientations of development of economic regions of Ukraine in the context of these conditions is a relevant problem which requires special study.

The objective of the study was determining the orientations of development of economic regions of Ukraine in relation to their complex resource provision and economic-geographic position. Use of the method of spatio-temporal analysis of economic regions of Ukraine as natural-economic geosystems for determining and explaining their current condition on the basis of statistical data allow us to predict tendencies of their development and to formulate certain recommendations on management of territorial development as a sphere of economic-geographical activity.

Materials and methods. Results and their analysis. Management of territorial development as a sphere of economic-geographical activity includes formation of regional statistics, socioeconomic zoning, geoexpertise and geoinformatics. They make it possible to assess the economic regions as regional economic systems with consideration of the effect of local peculiarities on economic activity. One should presume that improvement of management of territorial development can set requirements of changes in the corresponding normative framework. Currently, not enough attention is paid to the problems of territorial distribution of labour and social- geographic forms of intersectoral and interregional relationships on the basis of the principle of unity of nature, population and economy.

Territorial systems of different types have both common and specific properties. Coherence and interaction of these systems strengthen as the productive force develops, and manifests itself to a higher extent within the economic regions. An economic region is a fundamental regional structure which has a certain economic selfsufficiency and a property of self-organization. It can be considered as a set of economic subjects which create and use the natural-resources, workforce and infrastructural potential of the territory of its location. Taking into account the geographic factor is essential in designating economic regions as integral complexes which unite nature, demographic and economic components.

The natural and social basics of exploitation of nature are combined in geosystems. The components of natural potential are: geological, bioclimatic, physiological-climatic potential, etc. Natural-resource potential includes natural resources, the use of which is technically possible and economically practical (Bigger, 2018). In spite of this, in the context of a region's economy, it is important to determine its economic-geographic position as its basic benchmark of possibilities of development. Other components of economicgeographic position of a region can be considered to be: industrial-geographic position in relation to sources of energy and centers of processing industries; agrogeographic position in relation to the food base and centres of consumption of agricultural products; market position in relation to markets of selling the goods; demographic position in relation to workforce resources and scientifictechnical staff; recreational-geographic position in relation to the centres of recreation. Each of these components has a special development trend of its own and is connected to other components, forming a basis of geographical forecasting (Lucishin, 2001).

Geographic forecasting can be considered as a development of a system of understandings of the future properties and condition of territorial systems, the orientation of their changes. Economic-geographic forecasting is one of three types of geographic forecasting along with physical-geographic and geoeconomic forecasting. Economic-geographic forecasting determines the possible condition of territorial socio-economic systems in the future. It is conditioned not only by 
the objective conditions of economic-geographic location of a region and random factors, but also by orientation of the human activity.

As methodological base of economicgeographic forecasting, a system approach was used. A historical approach was also used, intended to take into account previous economic-geographic development in determining promising tendencies. The search of manifestations of future in the present is also important. Combining search and normative forecasting in integral forecasting makes it possible to improve the accuracy of forecasts (Topchiev, 2005).

In current conditions, in order to ensure the accuracy of economic-geographic forecasts, it is recommended to take into account not only the economic-geographic, but also the geopolitical location of a region in a single integral spatial category. The geopolitical location of a region is determined as its position in relation to the neighbouring countries, and first of all, to bordering regions with consideration of the ratio of geopolitical potentials, mutual geopolitical interests and problems. The special significance of geological position of bordering regions is related to the current conditions of globalization, international regionalization and integration. To the traditional components of economic-geographic position of the region, such components as financial-geographic position and innovationgeographic positions are being added. The financial-geographical position is the position of a region in relation to large financial and investing centers and countries with large investmentfinancial resources. Innovation-geographic position is the position of a region in relation to innovational centers and ranges of development of informational and high technologies (Smal, 2012).

In the research on economic-geographic aspects of development of the regions of Ukraine, it is impossible not to mention such important aspect as territorial distribution of labour. The science of territorial distribution of labour is a methodological basis for economic geography as science on territorial organization of economy. In this context, territorial distribution of labour is an objective process and a result of specialization of regions in producing different goods and providing services, conditioned by optimum ratio of local natural, economic and social conditions. A condition of territorial specialization is profitability of producing certain goods in amounts surplus to local needs and by means of costs which would be lower compared to the place of their consumption even if transportation is taken into account . Specialized regions can form trade connections with one another, creating an economically connected range. Thus, the territorial distribution of the workforce forms economic regions, separates them and at the same time connects them into a general economic range. Also, the extents of territorial specialization of production have their borders associated with the ecological-technogenic capacity of a given region, i.e. the borders, within which the production of certain goods causes no excessive harm to the natural environment of the region. In contemporary conditions, there is a tendency towards supplementation of the object specialization of the regions with detailed and operational specializations on the basis of international distribution of labour (Bliy, 2004).

The process of development of an economic region needs to be analyzed as a constant process of emergence and spreading out of new types of activities in it. For this purpose, each region has to accumulate a certain potential for involving new, more technically developed forms of production. At the same time, the idea of the close positions of interrelated industries remains one of the main ideas concerning the formation of the economy of economic regions. In general, increase in the efficiency of regulating territorial development is related to improvement of economic-geographic practice. The main orientations can be considered as follows: the development of regional statistics, indicative territorial planning, regional projecting, geographic expertise (Lagencev, 2002). Regional statistics should be based on geoinformational technologies. Also, the development of generally accepted acount-balances on the internal regional product is recognized as necessary, receiving of reports on the renewal of the entire materialtechnical base of the given economic region. Perhaps, in the future, regional statistics and geoinformatics will form an integral information block.

Indicative territorial planning suggests development of recommendations on positioning of productive forces and determination of the main spatial proportions of social renewal. Indicative planning does not mean strict division of resources, but rather a flexible indirect impact on certain units of production on the basis of use of such instruments as tax benefits, tax holidays, subsidies, subventions, etc. Regional projecting suggests projecting territorial socio-economic systems, mapping of interrelated positioning of industrial enterprises, engineering and transport communications, nature-protected objects, etc. Within the regional projecting, the activities of the economic objects should be negotiated in advance in relation to the complex use of the territory. 
Geographic expertise is orientated towards improvement of quality of information on the economic region, correlation of economic decisions with this information. Geoexpertise involves the analysis of the economic-geographic situation and modeling of a new one.

Economic regions can be considered integral territorial complexes which combine natural, demographic and economic factors and provide the main conditions of progressive development of a region. They include: social comfort which reflects the level and quality of the life of the population; polystructure which suggests presence of technological, economic, social, ecological, and informational subsystems; complementarity, i.e. receiving additional impulses of development within relations of subordination and coordination between economic subjects; self-development orientated towards achieving a situation when the separate elements of the economy become a system.

In the conditions of limited opportunities of state financing of development of economic regions, the task is to determine the priority regions at the moment, which at minimum capital investments can provide maximum profit for the country. At the same time, one cannot ignore the problem of non-uniformity of economic development of economic regions, and the consequent necessity of bringing them into closer alignment. For this purpose, it is practical to thoroughly analyze the advantages of each of the regions from the perspective of the entire complex of factors: economic-geographic position, resource base, and presence of qualified workforce, transport, information and social infrastructure, effective measures of institutions of power. Synergetic effect of these factors creates reasons for stable development of regions, harmonized within the country. Within social infrastructure, the educational potential of economic regions especially is significant. The preparation of specialists with higher education has a direct impact on the economic development of regions due to high probability of employing the graduates of higher education institutions in the cities where they are located. Corresponding statistics for economic regions indicates their ranking by number of higher education institutions: Capital economic region and city of Kyiv (157), NorthEast economic region (94), Carpathian economic region (89), Prydniprovsky economic region (79), Prychornomorsky economic region (78), Podillia economic region (59), Eastern economic region (42), Central-Ukrainian economic region (32), Volyn economic region (28). The ranking of economic regions by number of students is slightly different from that shown above and looks as follows: Capital economic region and city of Kyiv (418 913 people), North-East economic region (252 126 people), Carpathian economic region (213 804 people), Prydniprovsky economic region (180 523 people), Prychornomorsky economic region (165 592 people), Podillia economic region (116 920 people), Volyn economic region (57 761 people), Central-Ukrainian economic region (51 463 people), Eastern economic region (61 306 people). The provided data allow one to conclude that the top innovation-geographic positions are held by the Capital, North-East, Carpathian and Prydniprovsky regions.

Recently, specialists have increasingly added to these factors others such as the economic culture the residents of economic regions (Fritsch, 2017). This, in turn, is related to the peculiarities and traditions of communicativeness in each economic region. Communications in this context are considered as economic communication, formation of relations and connections between the economic subjects. The objects of such communication are traditional types of resources, as well as new, particularly: information and intellectual property. It is characteristic that for border economic regions, the priorities of closed economy change into the priorities of open economy. The decisive criterion of the effective economic culture is provision of a rational ratio between cooperation and competition in the region supported both by legislative norms and economic traditions.

Among the factors of contemporary economic zoning, one should remember historicalcultural traditions of geographic regions of Ukraine. The territory of Podniprovia mainly corresponds to the contemporary Prydniprovsky economic region. It is divided into Left-Bank Ukraine (Prydniprovia) and Right-Bank Ukraine (Zadniprovia). Left-Bank Ukraine included Chernihivshyna and Poltavshyna, and Right-Bank Ukraine - Kyivshyna and Bratslavshchyna. Zaporizhia was designated separately. Poltavshyna historically had agrarian specialization. Rural economy had a leading role in the economy of Chernihivshyna. Today, these territories are located outside the Prydniprovsky economic region. Its core in historic-geographic context is Zaporizhia which was located mainly in the territory of contemporary Dnipropetrovsk, Zaporizhia and Kirovohrad Oblasts. The main sectors of the economy of Zaporizhia have historically been hunting, fishing, animal husbandry, salt extraction, and trade. 
The territory of Sloboda Ukraine corresponds to the contemporary North-East economic region. A significant role in economy of the historical region was played by trade, craft, manufacturing production. Sloboda Ukraine has deep educational traditions: in XVIII century, 124 schools operated, and in Kharkiv Collegium, around 500 people studied. The traditions of a cultural-educational centre have remained in Kharkiv to this day. The dense forests of Sloboda Ukraine contributed to construction in the region, particularly of fortresses, windmills, etc. Extraction of salt in Tiurkski lakes, and also of chalk and clay conditioned specialization of this historical region. Fertile chernozem created conditions for arable farming and animal husbandry.

The historical region of the Donbas corresponds to the contemporary East economic region. Its name derives from the shortened name of the Donetsk coal basin. The Donbas is divided into the Eastern and Western Donbas. Today the Donbas is one of the most urbanized regions of the world. Since time immemorial, salt has been extracted there, and metallurgical, mining productions and blacksmithing have been conducted.

The historical region of Prychornomoria corresponds to the contemporary Prychornomorsky economic region. It is divided into Edisan, Dzhambailuk, Edishkul and Crimea. Edisan is a historical region of South Ukraine between the Dnister and Southern Buh. The main type of activity in this territory has been animal husbandry. Dzhambailuk is a historical region between the Dnipro and the Crimean Peninsula. Edishkul is the historical region located southwards from Zaporizhia on the eastern shore of the Dnipro. These regions were included in the Crimean Khanate.

Of the historical region of Bukovyna, in contemporary Ukraine, only Chernivtsi Oblast is included, which belongs to the Carpathian economic region. The economy of Bukovyna had an agrarian character.

Galicia is a historical region, which today includes the Ukrainian oblasts of Ivano-Frankivsk, Lviv and part of Ternopil Oblast, which belong to the Carpathian economic region (Ivano-Frankivsk and Lviv Oblasts) and Podilsky economic region (Ternopil Oblast). Since the long ago, salt has been obtained in Galicia by brine evaporation. In the XIXth century, oil deposits were found in the area. Trade and railway transport also developed.

Podillia is a historical and geographical region above the northern tributaries of the Middle Dnister and upstream of the Southern Buh. Today this region corresponds to the Podilsky economic region. Since historical times, trade and craft were developed in the area . In recent years, about 5500 industrial enterprises have functioned in Podillia, particularly, sugar, distilling enterprises, brickworks, pasta factories; woollen-goods and mechanical factories, paper mills, match factories, etc. A priority sphere was sugar production. Important railways were laid across the territory of Podillia.

Zakarpattia historical-geographic region covered the Zakarpatska Lowland, hills and southern slopes of the Carpathians. Today, its territory corresponds to part of the Carpathian economic region. In Zakarpattia Oblast, salt mines operated in the region in historical times, also blacksmithing and pottery, viticulture, and gold mining . In recent years, iron manufacturers, sawmills, coopering manufacturers, and coal mines have operated.

Volyn historical-geographic region was located in the basins of southern tributaries of the Pryviat and upstreams of the Western Buh. Its territory in contemporary Ukraine corresponds to the Volyn economic region. In the region, trade, agriculture and the lumber industry have intensely developed.

Polisia historical-geographic region is located in the territory of the Polesia Lowland. Today, its territory corresponds to part of the Capital and North-East economic regions of Ukraine. In the region, traditionally economic activities were agriculture, lumbering, extraction of coal and oil.

The historical-geographic regions of Ukraine do not completely coincide with the borders of the contemporary economic regions of Ukraine . In particular, Kyivshyna, which historically belongs to the region of Right-Bank Ukraine, today belongs to the separate Capital economic region. Kyivshyna included the central and southern regions with the center in Kyiv. In historical times, agriculture and craft were developed in region, and in recent decades - manufacturing production and education.

The abovementioned theoretical economicgeographic and historic-geographic locations allow one to assess the condition and potential of development of the economic regions of Ukraine and suggest possible scenarios of their development on the basis of improvement and diversification of their territorial specialization. According to the Law of Ukraine "On the concept of state regional policy", nine economic regions have been designated in Ukraine: Volyn, Carpathian, North-East, Podillia, Prydniprovsky, Prychornomorsky, Capital, Eastern and Central- 
Ukrainian economic regions. The economic regions of Ukraine are characterized by high extent of differentiation in the level of development. According to the obtained results, the best current condition was observed in the Capital, Prychornomorsky and Prydniprovsky economic regions. The lower values were obtained for the Eastern, Carpathian and Podillia economic regions. The average group in the rating of economic regions consists of the Volyn, North-East and Central-Ukrainian economic regions. Assessment of the potential of development of the economic regions of Ukraine indicated that the best positions belong to the Capital, Eastern and Prydniprovsky economic regions. The lowest positions among the economic regions belonged to the Volyn, Carpathian and Podillia economic regions. The average group in the ranking consists of the Central-Ukrainian, North-East and Prychornomorsky economic regions. The Capital economic region has a leading position by amount of investments in creating employment and qualification of the workforce. The Prychornomorsky region is characterized by low level of recorded unemployment. This economic region has a leading position by export of goods, which is a factor in the relatively high level of employment of the workforce.

The unsatisfactory current condition of the economy of the East economic region is to a great extent related to the complication of economic conditions, caused by the critical social-political situation. Problems of the Carpathian economic region are related to its low level of industrialization and difficult farming conditions . This leads to intense external migration of the workforce from this economic region to the bordering countries. Similar problems are characteristic of the Podillia economic region. The Volyn, North-East and Central-Ukrainian economic regions have an average level of industrialization and average-quality conditions of farming, which conditions their relative stability. As for the potential of development of the economic regions, in the Capital economic region, its high level is conditioned by development of informational-communicative technologies, provision with financial-investment resources, the educational potential of preparation of a highly qualified workforce. The high potential for development of the East and Prydniprovsky economic regions is to a high extent conditioned by the significant amount of natural resources with corresponding industrial infrastructure and educational specialization. The low potential of development of the Volyn, Carpathian and Podillia economic regions is related to limited provision with natural resources, absence of programmes of competitive specialization of these economic regions with corresponding provision with staff. The Central-Ukrainian, North-East and Prychornomorsky economic regions are orientated towards industrial production in the industrial sector of economy and services, which could be expected to show development without support of the state.

State regional policy suggests gradual alignment of social-economic level in different economic regions of Ukraine. Achieving this is impossible without an innovational approach and innovations in different spheres of the economy, including the spheres of state and regional management. The strategy of decentralization in the state's regional policy suggests increase in the role of territorial communities in all spheres of social life, including, the economic sphere. This becomes reflected in the prospects of changes in the structure of taxes and costs of state and regional budgets, increased self-sufficiency of Oblast communities in solving problems of development of infrastructure, including social elements, etc.

In these conditions, the central organs of state regulation of the economy can concentrate attention and efforts on formation and realization of a general strategy of social-economic development of the country, coordination of activity of the most aggregated territorial units, i.e. economic regions. Those who would introduce such strategy could be territorial institutions of state management of economic regions (ISMER). On the one hand, functioning of such institutions would take into account the specifics of the economic regions in historical, economic, and cultural aspects, and on the other hand would be a tool of introducing and realization of integral state strategy of socialeconomic development of the country.

One of the aspects of activity of ISMER should be regulating inter-regional and intraregional workforce migration. Today, workforce migration within Ukraine is characterized by a high level of migration to the Capital economic region, mainly to Kyiv. This is conditioned by the relatively high demand for a workforce in the capital, including workers with higher education and by the highest amount of direct foreign investments per economically active person, which is manifested by the large number of foreign companies, companies with foreign capital investments, in particular IT-companies. The ratio of the number of posted resumes and vacancies (hh-index) ranges from 2.5 to 25 . Such disproportions are a leading factor of workforce 
migration between economic regions. In terms of professions, the largest share of work immigrants to the Capital economic region is composed of IT specialists, managerial staff and sales specialists.

The main tendency of internal workforce migration is migration in the direction "villagecity" due to the better conditions of employment in cities. In inter-region workforce migration, the leaders of migration also are the North-East and Prychornomorsky economic regions. The least attractive regions for workforce migration are the Eastern, Prydniprovsky and Carpathian economic regions. Internal workforce emigration is characteristic of the Carpathian, Prydniprovsky, Volyn, and East economic regions. A major proportion of migration in all economic regions is taken by pendulum migration, which means that people travel to their workplace every day out of their settlements.

The concept of state migration policy in Ukraine does not consider internal migration as a strategic orientation of migration policy, which could lead to significant disbalance in territorial distribution of population. For preventing this, one should provide balanced development of economic regions, including by means of innovational differentiation approaches to stimulating economic activity in economic regions. These tasks should be solved by ISMER in accordance with analytical and forecasting data on development of the economic regions.

For the Carpathian economic region, investments in exploiting reserves of oil and gas of the Carpathian oil-gas province are relevant. Use of innovational technologies of extraction of oil and gas would contribute to increase in competitiveness of domestic hydrocarbons, reduction of their cost prices, therefore utility tariffs. This relates first of all to the Borodchanske deposit, and also deposits of shale gas in Odessa area, which according to experts`assessments equal 3 trillion cubic meters. Employment in the energy industry would significant decrease workforce migration from this economic region. Another direction of effective economic activity should be the extension of use of recreational resources of the Carpathian economic region, transforming it into a national and international touristic center. Innovational management is needed in Horany Nature Reserve and Karpatsky, Halytsky and Hutsulshchuna National Nature Parks. Eleven existing sanatoriums and the Bukovel ski resort do not exhaust the recreational potential of Carpathian economic region and this fact could therefore provide realization of the potential of employment of population in this sphere. Special attention should be paid to forestry and the forest economy of the Carpathian economic region. Investments in these spheres with participation of foreign capital, but with domination of domestic capital and with state support, could be a significant impulse for activation of economic activity and balance of the labour market in this economic region.

The Volyn economic region needs investments into modernization and development of extraction of brown coal in the Lviv-Volyn coal basin. The potential of the timber economy and machine-building industry in this region also have not been realized. This region with its rich history and original cultural and architectural relics could be one of the centers of national and international tourism, which would allow creation of thousands of jobs and reduction in the pressure on the labour market.

For the North-East economic region, it is vital to maintain and develop its industrial potential. This economic region is a region of workforce immigration. Its labour market differs by the high level of education and qualification of its workers. Along with the traditional machinebuilding industry, in this particular economic region, it would be practical to develop the microelectronic industry, producing equipment for information-communicative technologies.

The Podillia economic region needs investments into extraction of sand, limestone, chalk, and clay. This is one of the regions with a traditionally high rate of workforce emigration. Stabilization of the labour market in the Podillia economic region could be contributed by investments into development of recreational resources. Qualification measures in advertisement and marketing could involve thousands citizens of Ukraine and foreigners in tourism and recreation this economic region suggests over 400 territories and objects of the nature-reserve fund, including the Medobory Reserve, the Dnistrovsky Canyon, the Karst Caves, etc.

The Prydniprovsky economic region should compensate for the reduction in demand for products of black metallurgy by development of other spheres, traditional, as well as new spheres for the region, particularly: the space industry, microelectronics, production of home appliances, etc. This region could also attract tourists and travelers by historical reconstructions of the Zaporizhia Sich, restoration of traditions of craft and folk art.

Development of the Prychornomorsky economic region is to a high extent conditioned by its seaside position with large sea trade ports. Investments to this sphere should contribute to 
growth of employment and maintaining of balance on the labour market with consideration of the immigration character of the economic region. A significant role in activation of its economic activity should be played by use and development of resorts, including use of negative air ionization therapy, heliotherapy, thalassotherapy, etc. The East economic region needs first of all stabilization of the political situation and restoration of its traditional economic spheres. Also, this economic region needs diversification of its specialization, introduction of productions with high technologies, biotechnologies, which would contribute to the use of its high scientific potential and raising the labour market to a qualitatively new level. The CentralUkrainian economic region needs investments into mining of fossil fuels which are used at less than half capacity. The Central-Ukrainian region is characterized by a large amount of objects of cultural heritage, including such old cities with architectural relics as Uman and Kaniv. This creates conditions for development of tourism and employment in this sphere if the necessary state support is given.

For solving the abovementioned problems, one should create favourable investment climate involving both direct and portfolio investments, which would be differentiated by spheres in relation to the priorities of each economic region.

Conclusions. According to basic economicgeographic principles of zoning and using the method of spatio-temporal analysis of economic regions of Ukraine as natural-economic geosystems, a prediction of tendencies of their development towards closer mutual alignment and complementarity was made. It was suggested to take into account financial-geographic and innovation-geographic positions of the economicgeographic location of the regions. Certain recommendations for each economic region were developed for realizing their development potential in relation to the determined priorities.

\section{References}

Baranovskiy, M., 2009. Naukovi zasady suspilnogeografichnogo vyvchennya silskyh depresivnyh teritoriy Ukrainy [The scientific basis of the socialgeographic study of the agriculturally depressed territories of Ukraine]. Nigyn (in Ukrainian).

Bigger, P., 2018. Economic geography - a criterial introduction. Journal of Economic Geography, 18(6), 1343-1344.

Bliy, G., Muller, P., 2004. Geografia: svity, regiony, concepty [Geography: worlds, regions, concepts]. Libyd, Kyiv (in Ukrainian).
Clifford, N., French, S., Valentino, G., 2010. Key Methods in Geography. SAGE.

Cupach, T., 2015. Informaciyni technologii ta systemy v turizmi [Information Technologies and systems in tourism]. Kyiv (in Ukrainian).

Gomez, B., Jones, J., 2010. Research Methods in Geography. Blackwell Publishing.

Fritsch, M., Wyrwich, M., 2017. The effect of entrepreneurship culture. Journal of Economic Geography, 17(1), 157-189.

Hvesyk, M., 2012. Institucionalizacia pryrodno-resursnyh vidnosyn [Institutionalization of the natureresources relations]. Kyiv (in Ukrainian).

Kolomiec, K., 2017. Socialno-economichniy rosvitok regionu Ukrainskogo Prichornomoria na zasadah regionalistiky ta planuvannya teritorii [Socialeconomic development of the Ukrainian Black Sea region on the basis of regionalistic and planning of the territory]. Odessa (in Ukrainian).

Lagencev, V., 2002. Economico-geograficheskie aspekty upravlenia territorialnym razvitiem [Economic and geographical aspects of the management of territorial development ]. Econom. science of modern Russia, 2, 67-78 (in Russian).

Lucishin, P., Klimon, D., Lucishin, N., 2001. Teritorialna organizacia suspilstva (osnovy teorii) [Territorial organization of society (the base of theory)]. Vega , Luck (in Ukrainian).

Merezha vyschih navchalnyh zakladiv na pochatok 2017/18 navchalnogo roku (2018) [Network of universities in the start of the 2017/18 study year]. Retrieved from http://vnz.org.ua/10415-merezhavyschih-navchalnyh-zakladiv-na-pochatok201718-navchalnogo-roku.

Neshtaev, B., 2018. Problemy regionalnoi fizychnoi geografii, geoekologii ta geoistorichnogo analizu [Problems of regional physical geography, geoecology and geohistorical analysis]. Sumy (in Ukrainian).

Palamarchuk, M., Palamarchuk, O., 1998. Economichna i socialna geografia Ukraini $\mathrm{z}$ osnovamy teori [Economic and social geography of Ukraine with theoretical bases]. Kyiv (in Ukrainian).

Pasenko, L., Soroka, M., Kapirulina, S., 2010. Noviy dovidnyk. Geografia: zagalna geografia, geografia svitu, geographia Ukrainy [The new directory. Geography: general geography, geography of the world, geography of Ukraine]. Kyiv (in Ukrainian).

Smal, V., 2012. Globalni vikliky suchasnosty. Suspilnogeografichny vibyr [The global calls of modernity. Social-geographic voice]. Kyiv (in Ukrainian).

Sutkin, S., 2007. Rekreaciyna geografia [Recreation geography]. Sumy (in Ukrainian).

Topchiev, O., 2005. Suspilno-geografichni doslidgennya: methodologia, metody, metodiki [Socialgeographic researches: methodology, methods, ]. Astroprint, Odessa (in Ukrainian).

Udovichenko, V., 2009. Metody komplexnyh geografichnyh doslidgen [Methods of complex geographic research]. Kyiv (in Ukrainian). 